\title{
A SURVEY OF GREEN BURIAL SITES IN ENGLAND AND WALES AND AN ASSESSMENT OF THE FEASIBILITY OF A GROUNDWATER VULNERABILITY TOOL
}

\author{
K-H Kim ${ }^{a}$, M.L. Hall ${ }^{b}$ A. Hart ${ }^{c}$ and S.J.T. Pollard ${ }^{*}$

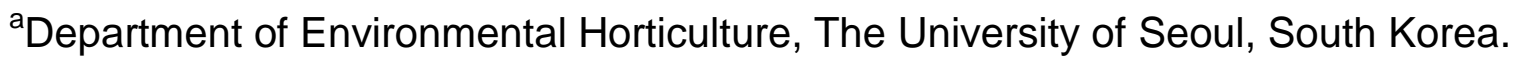 \\ bSustainable Systems Department, School of Applied Sciences, \\ Cranfield University, UK. \\ ${ }^{\mathrm{c} E n v i r o n m e n t ~ A g e n c y, ~ S c i e n c e ~ G r o u p, ~ S o l i h u l l, ~ U K . ~}$ \\ ${ }^{*}$ Corresponding author: Sustainable Systems Department, School of Applied \\ Sciences, Cranfield University, Cranfield, Bedfordshire, MK43 OAL, England, \\ Tel: +44 (0)1234 754101 e-mail: s.pollard@cranfield.ac.uk
}

\begin{abstract}
Since 1994, 200 'green' or natural burial sites have been developed in the UK and Eire, attracting regulatory attention because of perceived risks to groundwater. Here, a survey of natural burial practice in England and Wales ( $\mathrm{n}=49$ of 141 elicited) is presented, providing data on operational trends and supporting the design of a groundwater vulnerability assessment tool. Natural burial grounds are generally small in area $(<0.8$ ha), adopt a mean single burial depth of $1.45 \mathrm{~m} \mathrm{bgl}$ and a mean plot density of $c a .1480$ graves $^{-1}{ }^{-1}$. A vulnerability screening tool is described that allows a desk-based evaluation of sites by reference to seven groundwater risk attributes. Initial feasibility is evaluated through application to 131 sites. We offer
\end{abstract}


Keywords: cemetery, groundwater, pollution, natural burial grounds, risk, vulnerability.

There are two principal options for the disposal of the dead in the UK: cremation or burial. Cremation has been preferred for 40 years and in 2003 accounted for $75 \%$ of the funerals in England and Wales (Cremation Society of Great Britain 2003). But there is also considerable pressure for space in cemeteries. Furthermore, a growing demand for a more 'natural' way of burial has lead to the development of natural or 'green' burial grounds. Here, graves have no permanent gravestone or they posses an unobtrusive marker. Sites have a natural appearance, often taking the form of a managed woodland or meadow. Since 1994, ca. 200 sites in the UK and Eire have joined the Association of Natural Burial Grounds (ANBG) (Wienrich and Speyer 2003), the sector's trade body.

The potential for burial grounds to pollute the environment and the management of this risk is summarised by others (Pacheco et al. 1991; Janaway 1997; Dent and Knight 1998; Knight and Dent 1998; Young et al. 1999; Lelliot 2002; Spongberg and Becks 2000a,b; Dent et al. 2004; Environment Agency 2004a, Environment Agency 2004b; Hart 2005). When bodies and grave contents (coffins, coffin liners, shrouds, clothing) decompose, the decomposition products are released to the environment. The human body $(\mathrm{ca} .70 \mathrm{~kg})$ is a complex matrix of organic $(17 \% \mathrm{w} / \mathrm{w}$ protein; $17 \% \mathrm{w} / \mathrm{w}$ fat and $6 \% \mathrm{w} / \mathrm{w}$ carbohydrate) and inorganic $(\mathrm{N}, \mathrm{P}, \mathrm{Ca}, \mathrm{Na}, \mathrm{Sr})$ constituents. Decomposition poses a microbiological hazard. In risk assessment terms, there is a growing consensus that the principal receptor of concern for the key pollutants $\left(\mathrm{NO}_{3}{ }^{-}\right.$and $\mathrm{NH}_{4}{ }_{(\mathrm{aq})}$ ) is the groundwater below the site (Pacheco et al., 1991; Knight and Dent, 1998; Lelliot, 2002; Buss et al., 2003; Dent, 2005). 
This study provides the first survey of natural burial practice in England and Wales and describes the initial design of a groundwater vulnerability screening tool. The survey provides a unique snapshot of practices in this industry and the first qualitative information on the potential risks to groundwater. Both site operators and regulators in England and Wales (local authority planning and environmental health departments and their Government consultees, including the Environment Agency) must make decisions on the suitability of individual sites and, or, recommend site investigations where appropriate. In doing so, the first level of risk based decision making relies on screening the site against known likely hazard combinations. The original guidance on this subject (see Environment Agency 2004c) provided a similar framework which has been used in on some sites. At this screening stage, a full site characterisation and risk assessment of proposed burial grounds during the planning stages of their development is rarely possible. As a guide to prioritising sites that merit greater attention, this study proposes a risk screening methodology and examines its initial feasibility using a desk-based trial. The costs associated with detailed subsurface assessments are often too high for small sites. In addition, for extant sites there is the added reluctance of undertaking work that may disturb existing graves. Nevertheless, the method described here is based on bringing together existing tools such as the groundwater vulnerability maps that are widely recognised as appropriate to the screening step and are central to the regulatory response to any new developments that threaten groundwater quality.

\section{MATERIALS AND METHODS}

\section{Study rationale and natural burial ground survey}

Initially, a survey was undertaken to ascertain the state-of-the-art on natural burial grounds in England and Wales. A questionnaire (Table 1) was distributed to burial ground managers between April and June 2005 to characterise natural burial practice. Questionnaires were distributed to 141 members of the ANBG, the aim being to obtain a description of the source 
term and summarise the practices employed; data not previously compiled for England and Wales.

$<$ Table 1>

The questionnaire was designed to elicit information of the operational life (Q1), source term (Q2-6), depth of burial (Q7) and burial specifications (Q8-11).

\section{Groundwater vulnerability screening tool design}

For development of the groundwater vulnerability tool, both active and planned grounds whose location had been established were included. Site postcodes were used to extract the grid coordinates from the UK street map coordinate converter (http://www.streetmap.co.uk/gridconvert.html) and the coordinates used to reference relevant data from available spatial data sets. A baseline methodology for screening groundwater vulnerability to pollution from cemeteries is described by Young et al. (1999). The parameters used were: superficial deposit type and thickness, depth to water table, flow mechanism, presence and type of aquifer, source protection zone category and distance from watercourses, springs and drains. Since comprehensive data for each of these parameters are not available, the methodology was adapted, as shown in Table 2.

\section{$<$ Table 2>}

Each parameter (attribute; column 1, Table 2) was subdivided into categories representing an increasing risk to groundwater and a score assigned; 1-2 representing the least threat to groundwater and 9-10 the greatest. Scores for each attribute were equally weighted and summed to provide an aggregate vulnerability score across seven attributes (Tables 2 and 3). Adaptations made to the screening tool for each of the attributes are described below. Important limitations of the tool are discussed later. In some details especially because validation, in a metaphorical sense, is problematic for these scientific locations. 


\section{Type and thickness of superficial deposits}

Superficial deposits (regoliths) are interpreted as unconsolidated deposits that occur as discontinuous patches and larger spreads, resting on bedrock. Superficial deposit data at 1:50 000 was obtained from the British Geological Survey (BGS) (DiGMapGB-50 v2_11; British Geological Survey, 2005). Additional categories of superficial deposits to those described by Young et al. (1999) were assigned a vulnerability score (Figure 2). The thickness of the deposit was obtained from the BGS at the 1:50 000 scale from the GeoSure data set. The data is limited - it is modelled, created by interpolating values from borehole and map measurements. The basic superficial thickness model (BSTM) for deposit thickness was used. Wherever bore data is unavailable, this model uses a minimum mapped thickness of material of $1.5 \mathrm{~m}$.

\section{Hydrology of soil type models (HOST)}

While the Environment Agency holds some data on water table depth, a full national coverage is not available. Substitute data sets were therefore sought to provide an improved method for assessing groundwater vulnerability. The Hydrology of Soil Types (HOST) model (Boorman et al. 1995) has merit in this context because it assigns classes to soil types on the basis of their hydrological response and the representative processes occurring in soil (Figure 1). The HOST classes provide an indication of the degree of protection that an overlying soil provides to groundwater. A category of risk to groundwater for each HOST class was therefore assigned (Figure 2).

$<$ Figure 1>

Briefly, the HOST model catalogues soils on the basis of their physical properties and their effects on the storage and transmission of water. There are 29 HOST classes, based on 11 
response models, A-K (Table 2; Figure 2). Each model belongs to one of three groupings (horizontal rows in Figure 2), based on whether an aquifer is present and at what depth it is likely to occur: at more than $2 \mathrm{~m}$ depth, within $2 \mathrm{~m}$, or no significant aquifer or groundwater present.

$<$ Figure 2>

The HOST model describes the dominant water movement in soils (i.e. vertical or lateral) based on the soil properties of depth to gleyed layer, depth to slowly permeable layer, integrated air capacity and the presence of a peaty surface layer.

\section{Assignment of flow mechanism values}

The mechanism of water movement through soil influences the relative vulnerability of the underlying groundwater to pollutants. Intergranular flow is normally slower in the unsaturated zone than in the saturated zone. Water and dissolved pollutants travel downwards slowly allowing filtration and attenuation and thus providing a degree of protection to groundwater (Figure 1). In contrast, fissured flow enables pollutants to by-pass these attenuating processes. Flow mechanism scores were assigned using the HOST model (Figure 2), reflecting the spectrum of flow types from intergranular (1) to fissured (5). HOST models B and C, which contain an impermeable layer within $1 \mathrm{~m}$ or gleyed layer at $0.4-1.0 \mathrm{~m}$ and a gleyed layer within $0.4 \mathrm{~m}$ respectively, represent a range of substrate hydrogeology and no single flow mechanism can be assigned (Figure 2). Fortunately, model B (HOST class 13) and C (HOST class 14) account for only $0.5 \%$ and $0.03 \%$ of land in England and Wales and none of the burial sites fell into either of these classes. Raw peaty top soils dominate the hydrology of model D (class 15; Figure 2). While the underlying substrate is coarse and relatively permeable, the upper level is saturated. Model E is divided into two HOST classes, 7 and 8. Class 7 soils are made up of coarse textured sands and gravels in which by-pass flow is very uncommon; hence this class was assigned a flow mechanism of 1 . Class 8 was assigned a flow mechanism of 4 as it is comprised 
of loamy and clayey soils, but in which by-pass movement is often common via fissures and macropores.

\section{Source protection zones and aquifer data}

Source protection zone (SPZ) and aquifer data, part of the groundwater vulnerability mapping data set for England and Wales, were supplied by the Environment Agency (2001). Burial ground coordinates were compared with the source protection zones, and where the coordinates lay within zones II or III, the distance from the boundary between the two was measured using ArcMap ${ }^{\mathrm{TM}}$ software. The category 'close to boundary of zones II and III', not defined in Young et al. (1999), was taken to be $150 \mathrm{~m}$ from the boundary. The sites were scored for groundwater vulnerability for these two parameters as in Table 2 .

\section{Distances from watercourses, spring and drains}

Data on distances from drains and field are not collated on a national level. These features are critical and only identifiable through desk based research or site investigation. Distances from rivers, canals and lakes at 1:50 000 scale were provided by the Environment Agency. The scoring used in Young et al. (1999) was adapted: a distance of less than 30m between a burial ground and a river represents a high risk site. However, as the coordinates of the burial sites were generated from postcodes, the location of the sites does not have the required degree of precision to distinguish five different categories of risk. Instead, the sites were divided into three categories (Table 2): within $80 \mathrm{~m}$, between $80 \mathrm{~m}$ and $150 \mathrm{~m}$ and more than $150 \mathrm{~m}$ from a river or spring.

\section{RESULTS}




\section{Survey of natural burial ground practice}

To our knowledge this is the first survey of natural burial ground practice beyond the rudimentary information reported in Wienrich and Speyer (2003). Our survey of 141 sites elicited 49 responses. Natural burial grounds are operated privately, or by trusts or by local authorities. Almost $60 \%$ of sites in England and Wales are local authority-run and of the 49 respondents, 26 were from local authorities. Members of the ANBG have all opened since 1993 and been subject to modern planning procedures and statutory (Environment Agency) consultation on their siting. The following analysis is based on the 49 responses received.

\section{Site size and density of graves}

The area of burial grounds varied from 0.04 to 14 ha. Natural burial grounds are generally small sites, with half of the sites being $\leq 0.8$ ha. Only three sites are $>8$ ha, the mean size being 1.7 ha. The mean number of potential burials per site is 2637 and the mean plot density is 1478 graves ha ${ }^{-1}$. The plot density is consistent with the Environment Agency's estimated average of 1580 graves ha $^{-1}$ and lower than the typical density for conventional cemeteries of 1975 graves $\mathrm{ha}^{-1}$. The burial ground with the lowest projected density of burials has 165 graves $\mathrm{ha}^{-1}$; whereas the ground with the highest density has an average of $c a .9800$ graves ha ${ }^{-1}$ which appears anomalous. To estimate the rate of burial per site, each of the sites were asked how many burials occurred in each of the last four years (Table 1). In 2001, over 50\% of burial grounds undertook less than 5 burials. By 2004 this number had dropped to $40 \%$ and the percentage of sites with higher burial rates had increased (Figure 3).

<Figure 3> 


\section{Depth of graves}

The majority of natural burial grounds $(87 \%)$ dig graves to a single depth and inter a single coffin. By contrast, conventional cemeteries usually dig graves to inter two coffins. A survey of Danescourt cemetery in Wolverhampton, UK (Environment Agency 2002) found that $90 \%$ of the graves were for two coffins, at $1.8 \mathrm{~m}$ below ground level (m bgl). Deeper 'common graves' make up $2-3 \%$ of annual interments, typically extending to $2.7 \mathrm{~m} \mathrm{bgl}$ to contain three coffins. On occasion graves extend to $3.4,4.0$ or $4.6 \mathrm{~m} \mathrm{bgl}$, for four, five or six burials. The graves are normally filled within one year, so the source term may be treated as a single 'large burial' (Environment Agency 2004c). This survey suggests the mean burial depth in natural burial grounds is $1.45 \mathrm{~m} \mathrm{bgl}$. Whilst this is slightly deeper than the Agency model (Young et al., 1999), which assumes $1.3 \mathrm{~m} \mathrm{bgl}$, it is shallower than for conventional cemeteries. This potentially results in a slightly thicker layer of soil between the base of the grave and any underlying groundwater through which attenuating processes may occur, potentially lessening the potential polluting effects of the products of decomposition.

\section{Prior investigation and survey}

Nineteen of the responses indicated that no form of environmental site survey had been conducted before the site was opened. Eighteen respondents were aware of some form of prior investigation: in some cases a desk-based groundwater risk assessment had been conducted, boreholes sunk to monitor water quality or a soil or geological survey performed; in another case the local water utility had identified suitable locations using a desk-top analysis. At six grounds, respondents were unaware whether a survey had been conducted or not, possibly because the natural burial ground was annexed to an existing, older, cemetery. 


\section{Policies on embalming}

The recent development of natural burial grounds means they are unlikely to present a risk to groundwater from heavy metals employed in outdated embalming products, as these have been banned in England and Wales since 1951 (Select Committee on Environment, Transport and Regional Affairs, 2000). Nevertheless, current practice is sometimes to embalm using formaldehyde to arrest decay until after burial. The issue of accepting embalmed bodies for burial had not arisen at three grounds, and no policy had been fixed. Fourteen of the 49 respondents replied that they do not accept embalmed bodies. Twenty two sites responded without qualification that embalmed bodies are accepted, while 8 sites stated that although they preferred bodies not to be embalmed, they are flexible in practice.

\section{Coffin types}

Our study has adopted a premise that coffins adopted at natural burial grounds offer less containment for the contents than conventional coffins, many of which have plastic liners. In the survey, 33 responded that some form of discrimination was enforced. These sites described the types of coffin they accepted as 'biodegradable', 'environmentally-friendly', 'natural' or 'ecological'. Fourteen respondents listed the materials they accepted and these included bamboo, willow, cardboard, wicker and natural fibres. Sixteen respondents were prepared to accept any type of coffin, although 2 stated that the use of biodegradable coffins was encouraged.

\section{Tree cover and the interment of ashes}

Burial site managers were asked to provide an estimation of the tree cover over the site to compare with the Agency model for water infiltration and evapotranspiration (Young et al., 1999). Three of the sites had no tree cover, being meadows or pasture. Another 3 had no trees 
amongst the graves, but trees surrounded burials at the edge of the site. Twelve grounds estimated that $70-100 \%$ of the area of the site was covered by trees, and 8 stated that one tree was planted per grave. Fourteen sites estimated $2-40 \%$ tree cover. Six grounds made no estimate, but stated that tree cover would increase over time.

Space is not always planned for interring ashes. When asked about the provision of ashes plots on the site, 31 of the 49 respondents had planned the potential number of plots on the site and 11 replied that their site was capable of accepting the same number of ashes plots as graves; both types of internments being treated the same. Eighteen sites had no dedicated space for burying ashes, although some sites commented that families were welcome to scatter ashes at the site.

\section{Feasibility trial of the groundwater vulnerability tool}

We recognise at the outset the challenge of making risk- informed decisions with incomplete data sets. This sad, regulators face the challenge of offering a sound rationals for their advice whilst operating within these constraints.

\section{Screening tool output}

Of the 180 sites in England and Wales listed as members of the ANBG, 131 were identified and scored using the screening tool. Fewer locations than the listed 180 were identified because either no specific location existed for some planned sites, or because plans for the sites had been abandoned. Site scores were aggregated across seven risk attributes: (i) superficial deposit type; (ii) superficial deposit thickness; (iii) HOST classification; (iv) SPZ class; (v) aquifer type; (vi) flow mechanism; and (vii) distance to river. The scoring of these attributes was normalised, each attribute having a maximum score of 10 (9-10; Table 2). A maximum aggregate score of 66.5 (mean of the highest class score of $9.5 \times 7$ ) is achievable. The minimum vulnerability score theoretically achievable is $1.5 \times 7$, that is 9.5 . 
For to the total set of sites investigated of particular note was the high incidence of high scores (9-10) for deposit type and thickness, which results from the absence of superficial deposits. This was the case in $74(54 \%)$ of the sites screened. Deposit type is mapped throughout the country, although it occurs as discontinuous patches. Each site is mapped onto a deposit type, although over half of the sites have no underlying deposits. For example, one site (Headington, Oxford) was mapped to an area of peat deposits, although superficial deposits were absent at that location. Wherever borehole data is unavailable, the model provides a thickness of $1.5 \mathrm{~m}$. The data for 26 sites $(19 \%)$ gave a thickness of $1.5 \mathrm{~m}$, suggesting that accurate data may have been missing for as many as 26 sites.

Ninety sites scored 1-2 for HOST type. Only 8 burial grounds fell into the very high vulnerability class. One site (Entwhistle) was of HOST model K, which has raw peaty topsoil. The superficial deposits at this site, according to the BGS data, were diamicton, defined as "clay and silty clay, commonly pebbly and sandy, stiff, possibly interbedded with sand and gravel-rich lenses and rare peat" (British Geological Survey, 2005). Prior to this study, we anticipated that no sites would be located in Class I because the source water protection policy prohibits this type of land use within zone I. This appears to be accurate. Twenty-one sites are located in source protection zones II and III, the remainder lay outside the zones. There are no underlying aquifers at 30 sites; 80 sites occur over minor aquifers and 26 occur over major aquifers.

Determining the significance of risk in risk scoring systems is not straightforward, particularly for multiattribute systems such as the one described here. In all such systems there are the potential dangers of double counting and of assuming linear scales for individual attributes. We adopted a pragmatic approach to the analysis of the data here, being primarily interested in the relative banding of vulnerability scores than the absolute values obtained which are necessarily relative. Using the system developed a, 'moderate' score for each attribute would produce an aggregate vulnerability score of 35, whilst a 'high' score would produce an aggregate score of 63 and above (Table 2). In this feasibility assessment, we observed a concentration of 
aggregate scores around the mid range. For illustrative purposes, the aggregate scores for the highest scoring 30 sites $(n=131)$ are provided in Figure 4, which summarises the distribution of vulnerability scores by site identifier and attribute (note that all sites have a score $>40$ ). The distance to river, flow mechanism and aquifer type appear to be critical risk factors. Table 3 provides the raw data for the lowest eight scoring of these thirty sites as an illustration. We consider Figure 4 represents a series of 'medium risk' sites that subject to review, may warrant further investigation on an individual site basis, initially by desk-based scrutiny of the full data set and supporting assumptions in light of the fact that we are not able to yet validate the feasibility trial.

$<$ Figure 4>

$<$ Table 3>

\section{DISCUSSION}

Natural burials are on the increase in the UK and their impact on the environment is less well understood than those from crematoria or conventional cemeteries. When consulted on new development proposals, the Environment Agency advises local authorities on such sites. However, the science of natural burial grounds and, in particular, the extent and nature of the potential risks posed by bodies is not well understood. The vulnerability assessment tool designed and trialled in this study did not suggest any high-risk sites; a reassuring and positive outcome because these sites are either operational or in later stages of the planning process. This said, the study has highlighted the incomplete nature of several national data sets and demonstrated the critical importance of statutory consultation on siting decisions. By and large, those consultations that have taken place to date on the siting of natural burial grounds would appear to have been effective. 


\section{Methodological limitations}

All risk screening techniques, such as the one described in this study, have data limitations and simplifications embedded within them that demand scrutiny prior to their practical application. The regulator's challenge is to offer well-reasoned and proportionate advice, often in the face of a paucity of data or incomplete data sets and using assumptions that despite best intention, may not be able to be validated. Whilst adoption of a precautionary approach to siting decisions should err on the side of caution, seeking desk and site investigation data to support decisions, site investigation is not always practically possible and judgements have to be made used a wellreasoned rationale, hence the motivation for this study and feasibility trial.

Scores within ranking schemes represent surrogates for the true value of the attributes under study, and the aggregation of attributes across a complex system forces a caution on interpretations of the output. This screening tool is no exception. Source protection zones are centred on approximately 2200 major abstraction sites, some of which are used for public water supplies. Individual site investigations are required to identify additional sites of abstraction when considering new developments. An absence of data on drains and field drains is also an important limitation. No national data on smaller or private abstractions are available for a deskbased assessment of groundwater vulnerability. However, the same methodology may be employed for a more detailed on-site groundwater vulnerability assessment for the later stages of risk assessment. An identical scoring method may be used where smaller abstractions are made from viable aquifers.

A slightly different approach may be required when considering the presence of small local wells, where water is abstracted from shallow depths. The location of such wells is also unavailable on a national scale. Suitable soil types include HOST classes (Figures 1 and 2) within those described by HOST models $\mathrm{H}-\mathrm{K}$, where there is no underlying groundwater body. For example, HOST model I has an impermeable layer within $1 \mathrm{~m}$ and a gleyed layer between $0.4 \mathrm{~m}-1 \mathrm{~m}$, and model $\mathrm{J}$ has a gleyed layer within $0.4 \mathrm{~m}$. This results in much of the infiltrating 
rain being confined to the upper levels of the soil and moving in a predominantly lateral direction, such that water is held at shallower depths. If an on-site assessment is conducted and local wells identified, an amended scoring system is required.

Flow mechanism scores were assigned to HOST models. Scores were assigned solely on the basis of the method that water travels through soil, with the exception of Models $\mathrm{H}-\mathrm{K}$. These models describe soils which do not overlie any significant groundwater or aquifer. While these soils are slowly permeable or impermeable and may display fissured flow (mechanisms 4 and 5), particularly during summer months of low rainfall, there is no underlying groundwater or aquifer, so assigning a high risk score to these soils does not appear to be informative. For this reason, only low vulnerability scores (1-2) were assigned to these models. If an on-site risk assessment was to be conducted and the presence of local wells detected in areas of HOST models H-K, higher vulnerability scores would need to be assigned for flow mechanisms (7-8 for slowly permeable substrates and 9-10 for impermeable substrates). While hydrological processes described in the HOST models may be disrupted where the soil is disturbed for a grave, the main physical settings of the model are constant. In addition, water also infiltrates some of the ground between graves through undisturbed soil (e.g. at boundaries and services areas) and the HOST models hold true for the rainfall response in this soil.

Assigning the distance from the river line is the most problematic parameter, as distances have been measured from a single point within the sites. For the largest sites ( 8 ha and larger) the accuracy of this method is poor. The area of the site needs to be plotted in order to accurately measure the distance to the nearest river from the edges of the burial ground. Also, the distance from river lines was measured from the site-co-ordinates to the nearest river. The shortest distance between the two points was measured without taking into account topography. This potential source of error may result in an increased estimated risk to underlying groundwater because short distances can exist between sites and rivers without there being a hydraulic link between the two. 
The use of postcodes for the assessment does not provide the highest degree of precision for the location of sites, which may produce inaccurate scoring, particularly in rural areas. Also, point data were extracted from two-dimensional mapping information to perform the assessment. Mapped data consist of a series of polygons of varying sizes and shapes, each of which contain the values for that area. Analysis of sites at a higher level of sophistication is possible if the area of the site is used to conduct the assessment, rather than co-ordinates. Where site areas are used, the data from each polygon that intersects the site may be taken into account, providing a higher level of information about the site. If this methodology were used as part of the initial risk assessment in the planning process, the exact location and area of proposed sites would be submitted on an ordinance survey map as part of the planning application. This would permit a higher level of accuracy in the assessment.

Depth to water table was one of the original parameters assessed (Young et al., 1999). This is a key parameter to consider when assessing risks to groundwater and, because this information is not available for a desk-based study, the accuracy of our analysis remains somewhat impaired and constrained through application of the HOST scheme of water tables < or $>2 \mathrm{~m}$ depth. One methodological improvement would be to consider water tables of at least $2.5 \mathrm{~m} \mathrm{bgl}$, allowing for a further $1 \mathrm{~m}$ beyond the $1.45 \mathrm{~m}$ mean depth observed in the survey. The standard of the modelled superficial deposits thickness data includes significant data gaps and provides a simplified picture of superficial deposits.

To validate the initial approach presented here, we recommend that examples of natural burial grounds with the highest, median and lowest vulnerability scores be re-evaluated using data derived from site-specific measurements to determine if the results of the desk-based studies reflect field observations. With this level of validation, this method could be used to screen for high risk proposals early in the planning process. While this methodology was limited to the analysis of natural burial sites, it is equally applicable in principle to conventional cemeteries 
1 though the discrepancies with respect to burial depth are an important distinction between these classes of burial ground.

\section{CONCLUSIONS}

This first operational survey of natural burial grounds in England and Wales provides a summary of current practices and allows a comparison with conventional cemeteries. The principal distinctions are between burial depth and the number of burials per plot, coffin type and by inference, the degree of containment offered by coffins used at natural burial grounds. This needs to be considered alongside the possible routine collapse of conventional coffins postburial. The coordinates of 131 of 180 natural burial grounds have been used to extract nationally compiled data on seven physical parameters including superficial deposits type and thickness, distance to river, flow mechanism and HOST (hydrology of soil type) mechanism. These parameters were used to develop a groundwater vulnerability screening tool, the application of which was trialled scored for 131 sites and, in a first approximation, used to generate groundwater vulnerability scores. Finally, we have discussed in some depth the inherent limitations of the tool. These require additional attention prior to attempts to validate the tool's output with authentic site data from natural burial grounds. 
2 The Environment Agency funded Cranfield University's Centre for Resource Management and 3 Efficiency to undertake this work. We acknowledge the input of John Hollis, Christophe

4 Sannier, Pericles Toukiloglou, Elizabeth Farmer, Gregory Arends and Tomasz Tarchalski of 5 Cranfield University. Chris Moody at the Environment Agency extracted the distance from river $6 \quad$ line data. The opinions expressed herein are those of the authors' alone. 
1. British Geological Survey DiGMap General information notes, supplied with data, British Geological Survey, Keyworth, Nottingham, UK. (2005).

2. Boorman D.B., Hollis J.M. and Lilly A., (Hydrology of soil types: a hydrologically based classification of the soils of the United Kingdom. Report No. 126. Institute of Hydrology, Natural Environment Research Council, Wallingford, UK. (1995).

3. Buss S., Herbert A., Morgan P. and Thornton S., Review of ammonium attenuation in soil and groundwater. Quart. J. Engg. Geol. Hydrogeol. 37, 347-359 (2003).

4. Cremation Society of Great Britain (2003). Progress of cremation in the United Kingdom 1885-2003, available at http://www.srgw.demon.co.uk/CremSoc4/Stats/National/Progress.html, $<<$ accessed $16^{\text {th }}$ January 2006>>

5. Dent B.B. and Knight M.J.K., Cemeteries: a special kind of landfill. The context of their sustainable management. In: Groundwater: Sustainable Solutions, International Groundwater Conference, International Association of, Hydrogeologists, Melbourne Feb, pp. 451-456 (1998).

6. Dent B., Forbes S. and Stuart B., Review of human decomposition processes in soil. Environ. Geol. 45, 576-585 (2004).

7. Dent B.B., Vulnerability and the unsaturated zone - the case for cemeteries. In: Proceedings "Where Waters Meet", Joint Conference of the New Zealand Hydrological Society, International Association of, Hydrogeologists Australian Chapter) and New Zealand Soil Science Society, Auckland, Nov 30-Dec 2, 2005, paper A13 (2005).

8. Environment Agency Groundwater vulnerability maps, Environment Agency Bristol, UK. (2001). 
9. Environment Agency Groundwater impact of Danescourt cemetery, Wolverhampton, National Groundwater and Contaminated Land Centre Report NC/99/72, Solihull, UK. (2002).

10. Environment Agency Potential groundwater pollutants from cemeteries. Science Report. Prepared by A. Hart and S Casper, National Groundwater and Contaminated Land Centre, Solihull, UK. (2004a).

11. Environment Agency Assessing the groundwater pollution potential of cemetery developments, National Groundwater and Contaminated Land Centre, Solihull, UK. (2004b).

12. Environment Agency, Amendment to 'Pollution Potential Of Cemeteries' Young, C.P., Blackmore K.M., Reynolds P. and Leavens A. 1999, Draft Guidance. R\&D Report P223, Environment Agency, Bristol, UK. (2004c).

13. Hart A., Ammonia shadow of my former self, Land Contam. Reclam., 13, 239-243 (2005).

14. Janaway RC., The decay of buried human remains and their associated materials. In: Hunter J., Roberts C., Martin A (eds) Studies in crime: an introduction to forensic archaeology. Routledge, London, pp. 58-85 (1997).

15. Knight M.J. and Dent B.B., Sustainability of waste and groundwater management systems. In: Groundwater: Sustainable Solutions, Conference of the International Association of Hydrogeologists, Melbourne, Feb., pp. 359-374 (1998).

16. Lelliot M., Hydrogeology, pollution and cemeteries, Teaching Earth Sciences, 27, 68-73 (2002).

17. Pacheco A., Mendes J.M.B., Martins T., Hassuda S. and Kimmelmann A.A., Cemeteries - a potential risk to groundwater, Wat. Sci. Technol. 24, 97-104 (1991).

18. Select Committee on Environment, Transport and Regional Affairs (2000) Memorandum by the Environment Agency (CEM 56) 2000 Groundwater Pollution Potential of 
Cemeteries available at http://www.parliament.the-stationeryoffice.co.uk/pa/cm200001/cmselect/cmenvtra/91/91m62.htm, $<<$ accessed $16^{\text {th }}$ January, 2006>>.

19. Spongberg A., and Becks P., Inorganic soil contamination from cemetery leachate. Wat. Air Soil Pollut. 117, 313-327 (2000a).

20. Spongberg A. and Other Becks, P., Organic contamination in soils associated with cemeteries. J. Soil Contam., 9, 87-97 (2000b).

21. Wienrich S. and Speyer J., The Natural Death Handbook, 4th Edition. Rider, London. (2003).

22. Young C.P., Blackmore K.M., Reynolds P and Leavens A., Pollution potential of cemeteries: Draft guidance. R\&D Report, Environment Agency, Bristol, UK. pp. 223 (1999). 


\section{Sample survey questionnaire}

Name and address of burial site(s):

Postcode of actual burial site (s):

Contact name and/or email address:

1. When did the site open for burials?

Were any environmental surveys done before the site was opened?

If so, what was the nature of these?

2. What is the size of the burial site (acres)? (later converted to hectares)

Approximately what proportion of this is given over to tree cover?

Are there any intentions to expand the site?

3. In total, how many potential i) grave plots are there on the site?

ii) ashes plots are there on the site?

4. How many burials were there at the site in

0-5 6-10 $\quad 11-20 \quad 21-50 \quad$ more
i) 2004
ii) 2003
iii) 2002
iv) 2001
$\square$

$\square$

$\square$

5. How many burials in total have there been to date?

6. Are graves dug for each coffin, or are multiple coffins interred in single graves?

If a mixture of both practices is employed, what proportion of single and multiple graves are dug?

7. How deep are the graves i) for single coffins?

ii) for two coffins?

iii) for three coffins?

I'm also trying to establish whether the policy in burial grounds is to encourage more natural practices, or if the rules at burial sites are more prescriptive (and perhaps less flexible).

8. Which coffin types does the site accept?

9. What types of memorials are permitted on the site?

10. What requests are made of funeral directors using the burial site?

11. Does the site accept embalmed bodies for burial? 
Table 2

2 Adapted groundwater vulnerability scoring methodology (adapted from Young C.P., Blackmore K.M., Reynolds P. and Leavens A. 1999)

\begin{tabular}{|c|c|c|c|c|c|}
\hline parameter / score & $\begin{array}{l}\text { very low } \\
1-2\end{array}$ & $\begin{array}{l}\text { low } \\
3-4\end{array}$ & $\begin{array}{l}\text { moderate } \\
5-6\end{array}$ & $\begin{array}{l}\text { high } \\
7-8\end{array}$ & $\begin{array}{l}\text { very high } \\
9-10\end{array}$ \\
\hline \multirow[t]{2}{*}{ regolith type } & clay and silt & clay, silt and sand & $\begin{array}{l}\text { clay, silt, sand and } \\
\text { gravel }\end{array}$ & $\begin{array}{l}\text { sand } \\
\text { sand and gravel }\end{array}$ & absent \\
\hline & \multicolumn{4}{|c|}{$\begin{array}{l}\text { clay, silt, sand and peat } \\
\text { peat } \\
(2-3)\end{array}$} & \\
\hline superficial deposits thickness & \multicolumn{2}{|c|}{\begin{tabular}{l|l|}
$>5 \mathrm{~m}$ & $3-5 \mathrm{~m}$
\end{tabular}} & $3 \mathrm{~m}$ & $0-3 m$ & Absent \\
\hline HOST model classification & $\begin{array}{l}\mathrm{H}, \mathrm{I}, \mathrm{J}, \mathrm{K} \\
\text { (no significant aquifer or } \\
\text { groundwater) }\end{array}$ & C, D & $\begin{array}{l}\text { A, B, } \\
\text { (aquifer or groundwater } \\
\text { normally present at } \\
>2 \text { m depth) }\end{array}$ & $\mathrm{E}$ & $\begin{array}{l}\text { F, G } \\
\text { (aquifer or groundwater } \\
\text { normally present within } 2 \mathrm{~m} \text { ) }\end{array}$ \\
\hline flow mechanism & 1 (inter-granular) & 2 & 3 & 4 & 5 (fissured) \\
\hline Aquifer & none & & minor aquifer & & major aquifer \\
\hline Source protection zone & outside zone III & in zone III & $\begin{array}{l}\text { close to boundary of } \\
\text { zones II and III }\end{array}$ & within zone II & within zone I \\
\hline distance from river lines & $>150 \mathrm{~m}$ & & $80-150 \mathrm{~m}$ & & $<80 \mathrm{~m}$ \\
\hline
\end{tabular}


Table 3

2 Attributes scores and aggregated total for eight sites

\begin{tabular}{|c|c|c|c|c|c|c|c|c|c|c|c|c|c|c|c|}
\hline $\begin{array}{l}\text { site } \\
\text { ID }\end{array}$ & $\begin{array}{l}\text { superficial } \\
\text { deposits } \\
\text { type score }\end{array}$ & $\begin{array}{l}\text { mean } \\
\text { superficial } \\
\text { deposits } \\
\text { score }\end{array}$ & $\begin{array}{l}\text { superficial } \\
\text { deposits } \\
\text { thickness } \\
\text { score }\end{array}$ & $\begin{array}{l}\text { mean } \\
\text { thickness } \\
\text { score }\end{array}$ & $\begin{array}{l}\text { HOST } \\
\text { score }\end{array}$ & $\begin{array}{l}\text { mean } \\
\text { HOST } \\
\text { score }\end{array}$ & $\begin{array}{l}\text { SPZ } \\
\text { score }\end{array}$ & $\begin{array}{l}\text { mean } \\
\text { SPZ } \\
\text { score }\end{array}$ & $\begin{array}{l}\text { aquifer } \\
\text { score }\end{array}$ & $\begin{array}{l}\text { mean } \\
\text { aquifer } \\
\text { score }\end{array}$ & $\begin{array}{l}\text { flow } \\
\text { score }\end{array}$ & $\begin{array}{l}\text { mean } \\
\text { flow } \\
\text { score }\end{array}$ & $\begin{array}{l}\text { distance } \\
\text { from river } \\
\text { score }\end{array}$ & $\begin{array}{l}\text { mean } \\
\text { distance } \\
\text { from river } \\
\text { score }\end{array}$ & $\begin{array}{l}\text { mean } \\
\text { score }\end{array}$ \\
\hline 64 & $9-10$ & 9.5 & $9-10$ & 9.5 & $5-6$ & 5.5 & $1-2$ & 1.5 & $9-10$ & 9.5 & $3-4$ & 3.5 & $1-2$ & 1.5 & 40.5 \\
\hline 112 & $9-10$ & 9.5 & $9-10$ & 9.5 & $5-6$ & 5.5 & $3-4$ & 3.5 & $9-10$ & 9.5 & $1-2$ & 1.5 & $1-2$ & 1.5 & 40.5 \\
\hline 22 & $7-8$ & 7.5 & $7-8$ & 7.5 & $9-10$ & 9.5 & $1-2$ & 1.5 & $5-6$ & 5.5 & $7-8$ & 7.5 & $1-2$ & 1.5 & 40.5 \\
\hline 31 & $7-8$ & 7.5 & $7-8$ & 7.5 & $9-10$ & 9.5 & $1-2$ & 1.5 & $5-6$ & 5.5 & $7-8$ & 7.5 & $1-2$ & 1.5 & 40.5 \\
\hline 87 & $9-10$ & 9.5 & $9-10$ & 9.5 & $5-6$ & 5.5 & $1-2$ & 1.5 & $5-6$ & 5.5 & $3-4$ & 3.5 & $5-6$ & 5.5 & 40.5 \\
\hline 158 & $7-8$ & 7.5 & $7-8$ & 7.5 & $9-10$ & 9.5 & $1-2$ & 1.5 & $5-6$ & 5.5 & $7-8$ & 7.5 & $1-2$ & 1.5 & 40.5 \\
\hline 167 & $7-8$ & 7.5 & $7-8$ & 7.5 & $9-10$ & 9.5 & $1-2$ & 1.5 & $5-6$ & 5.5 & $7-8$ & 7.5 & $1-2$ & 1.5 & 40.5 \\
\hline
\end{tabular}




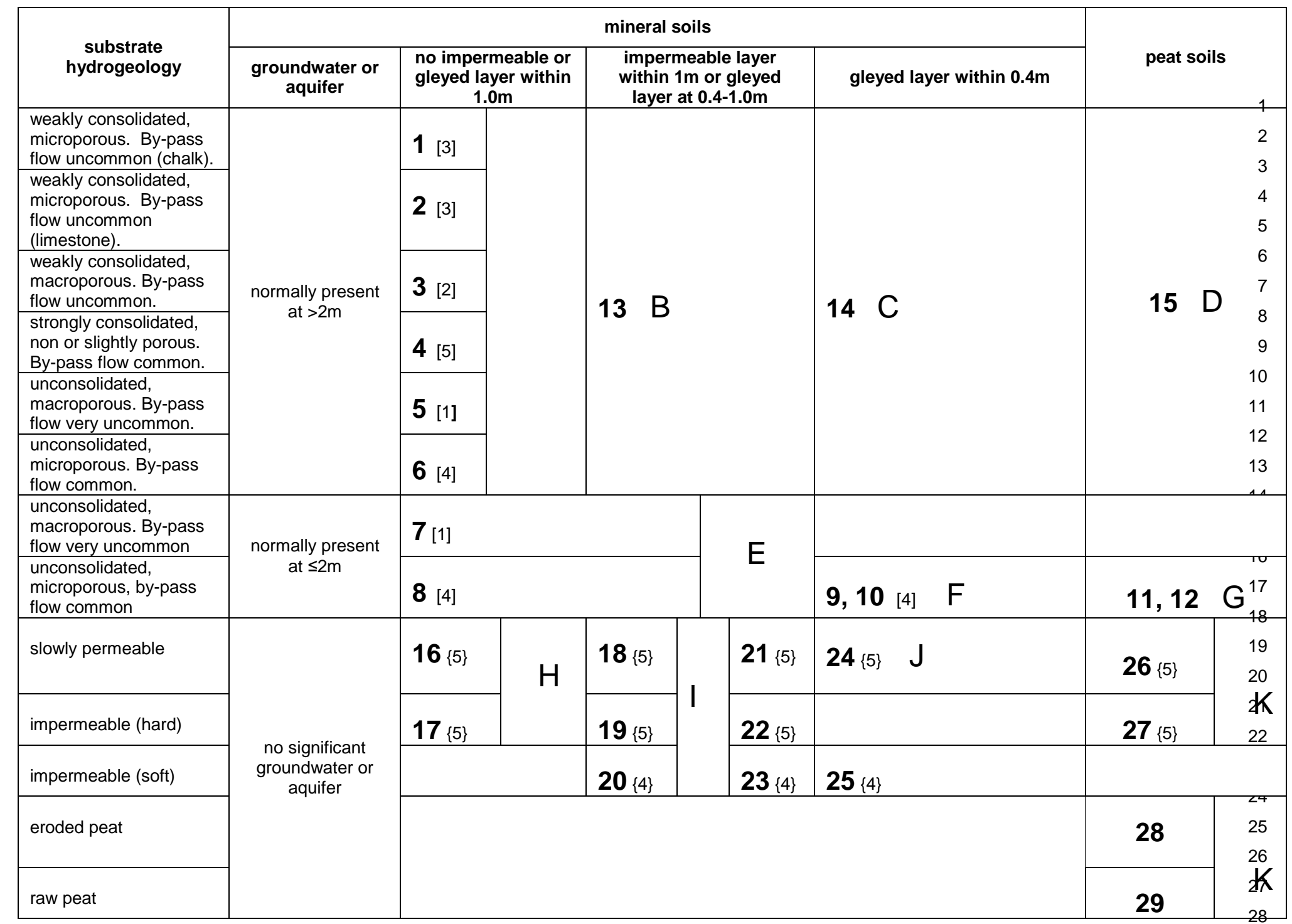

30 Figure 2. Host classification (1-29; A-K) and flow mechanism values to viable aquifers [in squared brackets]

31 and local wells in \{curved brackets\} (adapted from Boorman D.B., Hollis J.M., and Lilly A.1995). 


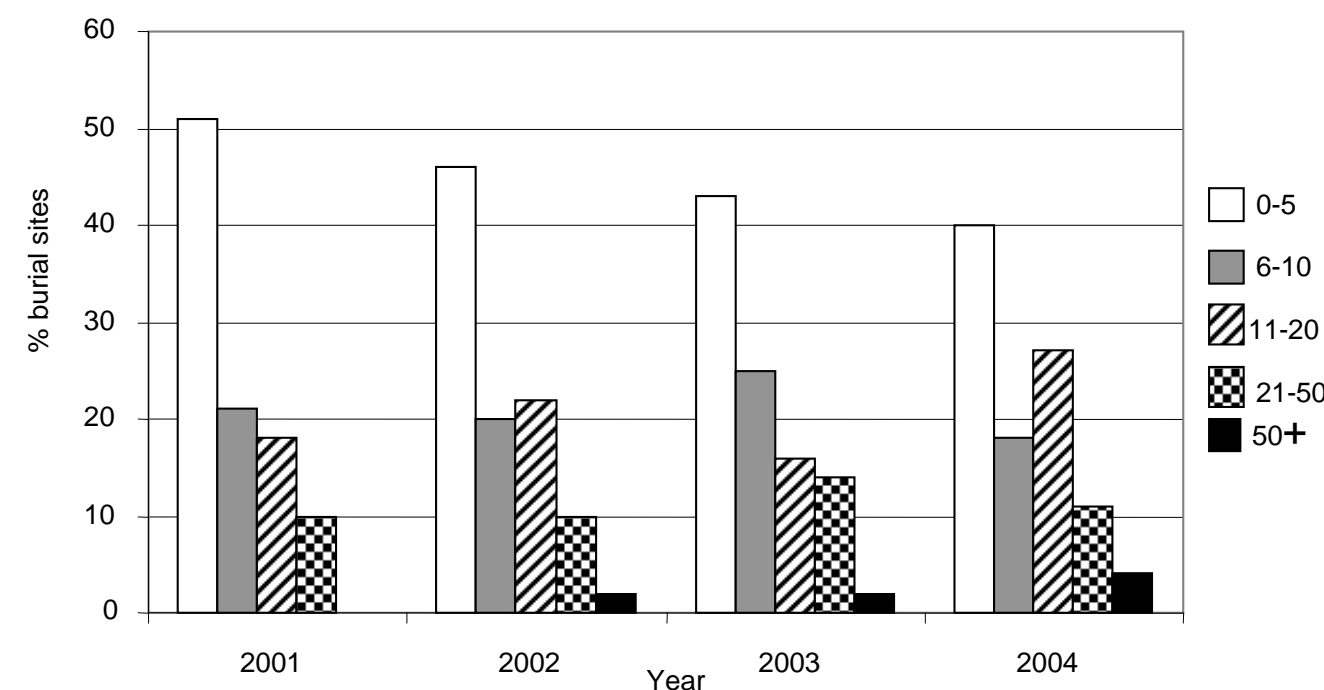

${ }_{3}^{2}$ Figure 3. Number of burials per site, 2001-2004 ( $n=49$ responses) 


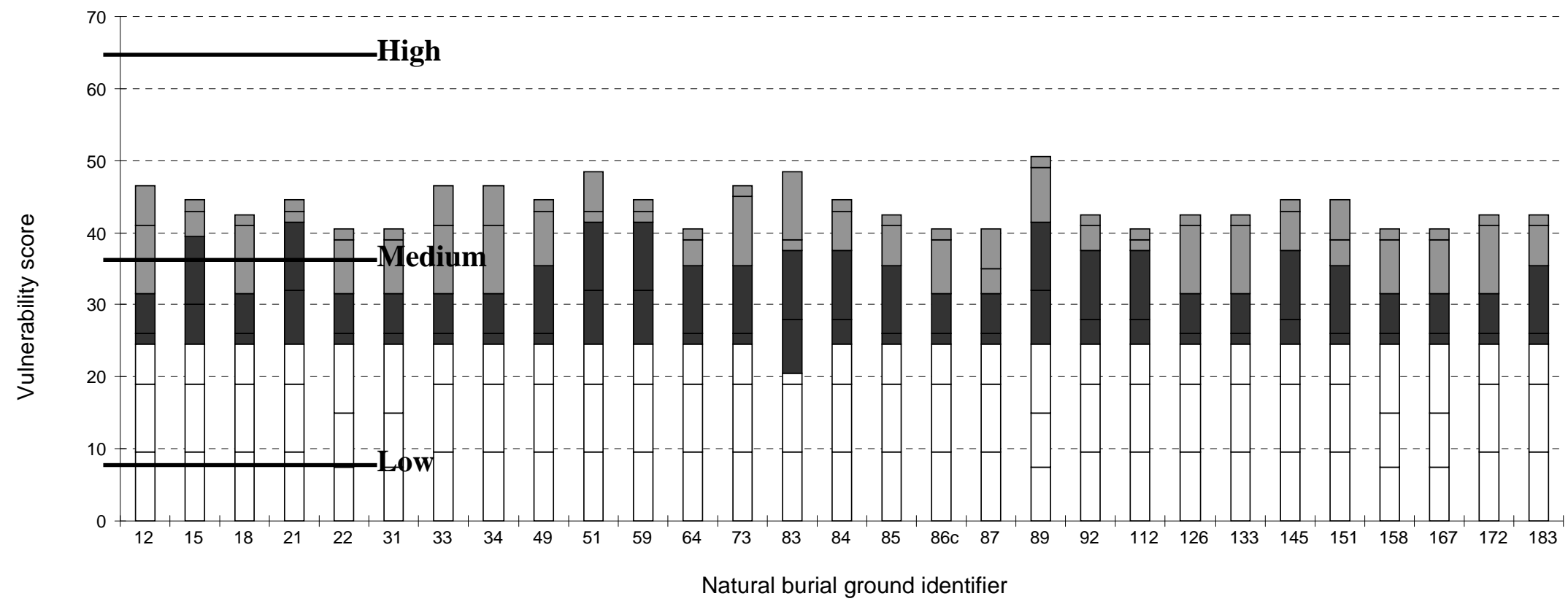

- Distance from river lines

$\square$ Flow mechanism

- Aquifer

$\square \mathrm{SPZ}$

- HOST model

- Drift thickness

$\square$ Drift type

Figure 4. Aggregated vulnerability scores and within-score distribution for 30 top scoring natural burial grounds 